\title{
Calcium Dependency and Free Calcium Concentrations during Insulin Secretion in a Hamster Beta Cell Line
}

\author{
A. E. Boyd III, Ronald S. Hill, James M. Oberwetter, and Maria Berg \\ Departments of Medicine and Cell Biology, Baylor College of Medicine, Houston, Texas 77030
}

\begin{abstract}
Using a glucose-responsive beta cell line, we tested the hypothesis that the free cytosolic $\mathrm{Ca}^{2+}$ concentration $\left(\left[\mathrm{Ca}^{2+}\right]_{1}\right)$ is the primary signal that couples a stimulus to insulin secretion, and examined the involvement of the extracellular $\mathrm{Ca}^{2+}$ pool in this process. Glucose or depolarization of the beta cell with $40 \mathrm{mM} \mathrm{K}^{+}$stimulated a monophasic release of insulin directly proportional to the extracellular $\mathrm{Ca}^{2+}$ concentration. $40 \mathrm{mM} \mathrm{K}^{+}$increased ${ }^{45} \mathrm{Ca}^{2+}$ uptake and increased $\left[\mathrm{Ca}^{2+}\right]$, which was measured with quin 2 , 4.7-fold, from $56 \pm 3$ to $238 \pm 17 \mathrm{nM}$. With high glucose, ${ }^{45} \mathrm{Ca}^{2+}$ uptake did not increase, and $\left[\mathrm{Ca}^{2+}\right]$ was unchanged or fell slightly. There was a striking correlation between inhibitory effects of verapamil, the $\mathrm{Ca}^{2+}$ channel blocker, on insulin secretion and the rise in $\left[\mathrm{Ca}^{2+}\right]_{1}$ evoked by $\mathrm{K}^{+}$. Higher concentrations of verapamil were required to inhibit glucose- than $\mathrm{K}^{+}$-stimulated insulin secretion (dose giving half-maximal effect of $1.4 \times 10^{-4}$ $\mathrm{M}$ vs. $6.0 \times 10^{-7} \mathrm{M}$ ). Incubation in $\mathrm{Ca}^{2+}$-free, $1 \mathrm{mM}$ EGTA buffer for $30 \mathrm{~min}$ lowered $\left[\mathrm{Ca}^{2+}\right]$ to $14 \pm 2 \mathrm{nM}$, and inhibited acute insulin release to both secretagogues. If high glucose was present in the $\mathrm{Ca}^{2+}$-free period, reintroduction of $2.5 \mathrm{mM} \mathrm{Ca}{ }^{2+}$ in high glucose restored insulin secretion only to the basal rate. However, if low glucose was present during the $\mathrm{Ca}^{2+}$-free period, high glucose and $2.5 \mathrm{mM} \mathrm{Ca}^{2+}$ triggered a full first-phase insulin response. These data suggest that high glucose generates a non$\mathrm{Ca}^{2+}$ signal that turns over rapidly and provide direct evidence that $\mathrm{K}^{+}$triggers insulin release by drawing extracellular $\mathrm{Ca}^{2+}$ into the beta cell through verapamil-sensitive $\mathrm{Ca}^{2+}$ channels. However, an increase $\left[\mathrm{Ca}^{2+}\right]$ is not the primary signal that evokes glucose-stimulated insulin release in this beta cell line.
\end{abstract}

\section{Introduction}

We have been using an SV40 transformed beta cell line (HIT cells) as a model system to further define the molecular mechanisms of insulin secretion $(1,2)$. In perifusions of HIT cells, high glucose or $40 \mathrm{mM} \mathrm{K} \mathrm{K}^{+}$evoke a monophasic, unsustained burst of hormone secretion. Extensive studies in islets and insulinomas suggest that the free cytosolic $\mathrm{Ca}^{2+}$ concentration, $\left(\left[\mathrm{Ca}^{2+}\right]_{\mathrm{i}}\right),{ }^{1}$ is the major intracellular signal that triggers exocytosis.

Address reprint requests to Dr. Boyd.

Received for publication 29 May 1985 and in revised form 6 September 1985.

1. Abbreviations used in this paper: $\left[\mathrm{Ca}^{2+}\right]_{\mathrm{i}}$, free cytosolic $\mathrm{Ca}^{2+}$ concentration; DMSO, dimethylsulfoxide; $\mathrm{ED}_{50}$, dose giving $50 \%$ maximal effect; $F_{\max }$, maximal fluorescence; $F_{\min }$, minimal fluorescence; KRB, KrebsRinger bicarbonate; quin 2/AM, the acetoxymethyl ester of quin $2 ; r^{2}$, coefficient of determination.

J. Clin. Invest.

(c) The American Society for Clinical Investigation, Inc. 0021-9738/86/03/0774/08 \$1.00

Volume 77, March 1986, 774-781
Until recently, the evidence to support this view was inferred from either ${ }^{45} \mathrm{Ca}^{2+}$ flux studies (3), or the extracellular $\mathrm{Ca}^{2+}$ requirement for insulin release $(4,5)$. One secretagogue where $\mathrm{Ca}^{2+}$ appears to be the signal for release is high $\mathrm{K}^{+}$concentrations that depolarize the plasma membrane opening voltage-dependent $\mathrm{Ca}^{2+}$ channels, allowing $\mathrm{Ca}^{2+}$ to enter the beta cell (4-8). How the extracellular $\mathrm{Ca}^{2+}$ pool is involved and the identity of the intracellular signal for glucose-stimulated insulin release are still unclear (9-13).

With the fluorescent $\mathrm{Ca}^{2+}$-indicator, quin 2 (14), it is now possible to measure $\left[\mathrm{Ca}^{2+}\right]_{\mathrm{i}}$ in small cells. Quin 2 is highly charged and does not cross the plasma membrane; however, a nonpolar methyl-ester derivative, quin 2/AM, readily enters cells where it is hydrolyzed by esterases to quin 2 . Upon binding to $\mathrm{Ca}^{2+}$, the intensity of quin 2 fluorescence increases and fluorescence is monitored continuously in cell suspensions to measure $\left[\mathrm{Ca}^{2+}\right]_{i}$. Recently Wollheim and Pozzan (7) and Rorsman et al. $(15,16)$ reported that $\mathrm{K}^{+}$-stimulated insulin secretion in a rat insulinoma cell line (RINm5f) is accompanied by a rise in $\left[\mathrm{Ca}^{2+}\right]_{i}$. In Wollheim's studies, the metabolizable secretagogues, alanine and glyceraldehyde, also raise $\left[\mathrm{Ca}^{2+}\right]_{i}$. Although the initial studies of RINm5f cells showed glucose responsiveness (17), subsequent investigations from a number of laboratories $(7,18)$, including our own (19), have not found this cell line, when grown in vitro, to be acutely responsive to glucose. Furthermore, $\left[\mathrm{Ca}^{2+}\right]_{i}$ falls in RIN cells exposed to glucose (15). Since other insulinomas also do not respond acutely to glucose, the HIT cells offer a unique opportunity to study the glucose signaling mechanisms.

To directly test the hypothesis that a rise in $\left[\mathrm{Ca}^{2+}\right]_{i}$ is a key signal for insulin secretion, we have compared the involvement of the extracellular $\mathrm{Ca}^{2+}$ pool in glucose- and $\mathrm{K}^{+}$-stimulated insulin secretion and the effect of both secretagogues on $\left[\mathrm{Ca}^{2+}\right]_{i}$.

\section{Methods}

Reagents. We obtained bovine serum albumin (fraction V, RIA grade), Hepes, and EGTA from Sigma Chemical Co., St. Louis, MO; fetal bovine serum and RPMI-1640 medium from Gibco, Grand Island, NY; ${ }^{125}$ I from Amersham Corp., Arlington Heights, IL; ${ }^{45} \mathrm{CaCl}_{2}$ from New England Nuclear, Boston, MA; and porcine insulin from Eli Lilly \& Co., Indianapolis, IN. Quin 2 and the acetoxymethyl ester of quin 2 (quin 2/AM) were purchased from Calbiochem-Behring Corp., San Diego, CA. Verapamil was a gift from G. D. Searle and Co., Skokie, IL.

Insulin assay. Insulin was measured using a double-antibody radioimmunoassay modified from that of Hales and Randle (20) as previously described (21). The anti-insulin antibody was raised in guinea pigs against porcine insulin.

Cell culture and perifusion. The HIT cell subclone T15 was obtained from Dr. R. Santerre of Eli Lilly \& Co. (22). The cells were grown at $37^{\circ} \mathrm{C}$ in $5 \% \mathrm{CO}_{2}$ and air, and maintained in RPMI- 1640 medium with $10 \%$ fetal bovine serum as previously described $(1,2)$. The perifusion system has also been described in detail $(1,2)$.

Insulin secretion in static incubations. HIT cells were plated into 12well Costar plates $\left(3 \times 10^{5}\right.$ cells $/ 25-\mathrm{mm}$ well) and grown for $3 \mathrm{~d}$. On the day of the experiment, growth medium was removed and the cells were 
preincubated for $45 \mathrm{~min}$ in Krebs-Ringer bicarbonate (KRB) basal buffer. This was followed by a second incubation in basal buffer for $15 \mathrm{~min}$, and a third incubation for $15 \mathrm{~min}$ in buffer containing the secretagogue. Test agents were present throughout the experiment. The buffer was saved and insulin content measured by radioimmunoassay. In a number of experiments, protein determinations were also performed. No differences were found when the data was expressed as insulin secretion per milligram of protein or per well.

${ }^{45} \mathrm{Ca}^{2+}$ uptake. ${ }^{45} \mathrm{Ca}^{2+}$ uptake was measured by the method of Tan and Tashjian (23), decreasing the $\mathrm{CaCl}_{2}$ content of the buffer to $1 \mathrm{mM}$ to increase the ${ }^{45} \mathrm{Ca}^{2+}$ uptake. The cells were incubated with a buffer containing 1-2 $\mu \mathrm{Ci}^{45} \mathrm{Ca}^{2+} / \mathrm{ml}$ and $\mathrm{Ca}^{2+}$ uptake determined at $2.5,5,15$, 30 , and $60 \mathrm{~min}$. Stimulation was terminated by quickly washing the cells three times with ice-cold buffer and solubilizing the cells with $0.1 \mathrm{~N}$ $\mathrm{NaOH}$. Aliquots were counted on a Packard Tri Carb Scintillation counter using ACS scintillation fluid from Amersham Corp.

Loading with quin 2. On day 3 or 4 after subculture, the cells were detached with trypsin $(0.1 \%)$ in Puck's saline A, counted, centrifuged for $2 \mathrm{~min}$ at $300 \mathrm{~g}$, and resuspended at a concentration of $20 \times 10^{6}$ cells/ $\mathrm{ml}$ in modified $\mathrm{KRB}$ (KRB with $20 \mathrm{mM}$ Hepes, $1.5 \mathrm{mM} \mathrm{CaCl}_{2}, 1.67$ $\mathrm{mM}$ glucose, and $5 \mathrm{mg} / \mathrm{ml}$ bovine serum albumin). The cells were then preincubated for $15 \mathrm{~min}$ at $37^{\circ} \mathrm{C}$ with gentle agitation. Quin 2/AM, stored desiccated at $-20^{\circ} \mathrm{C}$ as a $20-\mathrm{mM}$ stock in dimethylsulfoxide (DMSO), was added to a final concentration of either 50 or $100 \mu \mathrm{M}$. The final concentration of DMSO was $0.5 \%$. The cell suspension was mixed, incubated at $37^{\circ} \mathrm{C}$ with gentle agitation for $30 \mathrm{~min}$, then diluted with modified $\mathrm{KRB}$ to $4-10 \times 10^{6}$ cells/ml. The incubation was continued for another $50 \mathrm{~min}$. The cells were then centrifuged for $2 \mathrm{~min}$ at $300 \mathrm{~g}$ and resuspended in modified KRB to the same concentration of 4-10 $\times 10^{6} \mathrm{cells} / \mathrm{ml}$, and this washing procedure repeated once. The cell suspension was equilibrated to room temperature and the $\mathrm{pH}$ adjusted to 7.4. In each experiment, viability was determined by trypan blue exclusion and was always $>90 \%$ for up to $3 \mathrm{~h}$.

Fluorescence measurements. The cell suspension in $1.5 \mathrm{ml}$ (usually $4 \times 10^{6}$ cells $\left./ \mathrm{ml}\right)$ was placed in a square quartz cuvette $(1 \times 1 \mathrm{~cm})$ and stirred continuously. In each experiment hydrolysis of the quin 2/AM was determined by monitoring the emission spectrum, which shifted to a peak at $492-495 \mathrm{~nm}$ in $75-80 \mathrm{~min}$. The excitation wavelength was $340 \mathrm{~nm}$ and emission was measured at $492 \mathrm{~nm}$. The band pass was 10 $\mathrm{nm}$ for both excitation and emission. A Perkin-Elmer LS-5 fluorescence spectrophotometer equipped with a 3600 LS data station and a model 660 printer were used. Test agents were added from concentrated solutions. The ionized free $\mathrm{Ca}^{2+}$ concentration in the buffer measured using $\mathrm{a} \mathrm{Ca}^{2+}$ electrode was $1.2 \mathrm{mM}$.

Calibration of quin 2 fluorescence. Loading efficiency, defined as the percent of quin 2/AM molecules hydrolyzed and trapped as quin 2, was determined by measuring total fluorescence of cells in loading buffer with quin 2/AM and measuring fluorescence of cells alone after centrifugation $(19,000 \mathrm{~g}$ for $60 \mathrm{~s})$ and resuspension. The loading efficiency varied between 28 and $42 \%(n=4)$. The cellular quin 2 concentration measured by loading $20 \times 10^{6}$ cells in $100 \mu \mathrm{M}$ quin 2/AM, determining the cytocrit and calculating the intracellular concentration of quin 2 , was $1.8 \pm 0.2 \mathrm{mM}(n=6)$.

Because of quin 2 leakage, which results from cell damage during centrifugation and resuspension (7), corrections for extracellular quin 2 concentrations were necessary. Leakage was greater at $37^{\circ} \mathrm{C}$ than at room temperature. We therefore measured $\left[\mathrm{Ca}^{2+}\right]_{i}$ at room temperature. We corrected for leakage using the following procedure. EGTA in Tris buffer was added to the cell suspension while monitoring fluorescence. The rapid reduction in fluorescence represents extracellular quin 2 . The cells were then lysed with $50 \mu \mathrm{M}$ digitonin and fluorescence measured. This final measurement represents minimal fluorescence $\left(F_{\min }\right)$. Usually $F_{\min }$ was reached within $1.5 \mathrm{~min}$ after addition of digitonin. Maximum fluorescence $\left(F_{\max }\right)$ was determined by adding $\mathrm{CaCl}_{2}$ to the cuvettes. The minimum amount of $\mathrm{Ca}^{2+}$ necessary to saturate quin 2 was determined for each experiment. This is necessary because it was found that addition of $\mathrm{Ca}^{2+}$ after quin 2 saturation was reached decreased fluorescence. Usually $F_{\max }$ was reached with a total $\left[\mathrm{Ca}^{2+}\right]$ of $4.1 \mathrm{mM}$, which gives a cal- culated free $\left[\mathrm{Ca}^{2+}\right]$ of $100 \mu \mathrm{M}$. The $K_{d}(115 \mathrm{nM})$ for $\mathrm{Ca}^{2+}$ binding to quin 2 used in these experiments was the same as that determined by Tsien et al. (14).

Dependence of fluorescence on quin 2 concentration. To determine if the basal $\left[\mathrm{Ca}^{2+}\right]_{i}$ was altered by the amount of quin 2 in the cells, measurements were made comparing fluorescence between cells loaded with 50 and $100 \mu \mathrm{M}$ quin 2/AM. We found no significant differences between the basal $\left[\mathrm{Ca}^{2+}\right]_{\mathrm{i}}$ whether 50 or $100 \mu \mathrm{M}$ quin $2 / \mathrm{AM}$ was loaded.

Insulin secretion in quin 2-loaded cells. Two groups of cell suspensions were prepared. Control cells treated with DMSO and experimental, quin 2-loaded cells were washed, resuspended in modified KRB buffer without glucose, incubated for $30 \mathrm{~min}$ at $37^{\circ} \mathrm{C}$, centrifuged, and aliquots of 0.5 $\times 10^{6}$ cells were placed into $12 \times 75$-mm test tubes. After a 15 -min basal period in KRB containing $0.3 \mathrm{mg} / \mathrm{ml}$ glucose, the buffer was removed and the cells incubated for another $15 \mathrm{~min}$ in buffer containing the appropriate secretagogues. After centrifugation, the supernatant insulin concentration was measured. The cell pellet protein content was measured by the Lowry method (24).

Statistics. All values are expressed as the mean \pm SE. In perifusion, basal secretion is defined as the mean secretion rate in microunits per minute per plate during the final $5 \mathrm{~min}$ of the stabilization period; for static incubations, basal secretion is defined as the amount of insulin released during the final 15-min basal period. Statistical comparisons were made using the $t$ test or one-way analysis of variance where appropriate (25). The coefficient of determination $\left(r^{2}\right)$ was calculated for the simple linear regression.

\section{Results}

Glucose-stimulated insulin secretion: dependence on extracellular $\mathrm{Ca}^{2+}$. As previously shown in perifusion (2), insulin secretion falls and reaches a stable rate (data not shown) during the 30min stabilization period. Increasing the glucose concentration from 0 to $19.7 \mathrm{mM}$ increased insulin secretion from $0.4 \pm 0.2$ $\mu \mathrm{U} / \mathrm{min}$ per plate to a peak of $8.9 \pm 0.8 \mu \mathrm{U} / \mathrm{min}$ per plate. Peak secretion in each chamber was reached 6-8 min after switching to high glucose. After a 30-min period in $\mathrm{Ca}^{2+}$-free basal buffer (no added $\mathrm{Ca}^{2+}$ plus $1 \mathrm{mM}$ EGTA), $19.7 \mathrm{mM}$ glucose in $\mathrm{Ca}^{2+}$ free KRB failed to stimulate insulin secretion (Fig. 1). Total insulin released in response to high glucose during the $\mathrm{Ca}^{2+}$-free period (30-50 $\mathrm{min}$ ) was $4.0 \pm 2.5 \mu \mathrm{U} /$ plate compared with $94.4 \pm 7.8 \mu \mathrm{U} /$ plate for the controls $(n=4, P<0.0001)$. When a perifusion buffer containing $2.5 \mathrm{mM} \mathrm{Ca}^{2+}$ and high glucose replaced the $\mathrm{Ca}^{2+}$-free buffer at $50 \mathrm{~min}$, the insulin secretory

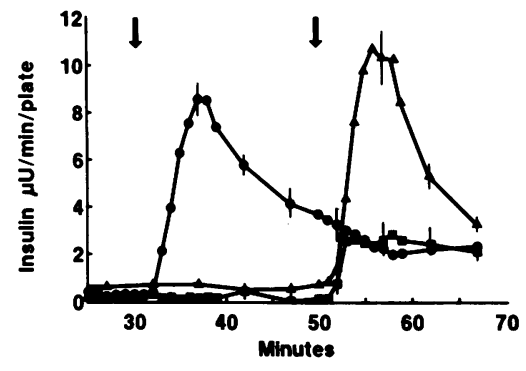

Figure 1. Calcium dependence of glucose-stimulated insulin secretion. Control HIT cells stimulated with $19.7 \mathrm{mM}$ glucose (first arrow) in 2.5 $\mathrm{mM} \mathrm{Ca}{ }^{2+}$ buffer $(\bullet, n=4)$ responded with a monophasic insulin response. Cells stimulated in $\mathrm{Ca}^{2+}$-free buffer (no added $\mathrm{Ca}^{2+}$ plus $1 \mathrm{mM}$ EGTA $(n, n=4)$ did not respond (30-50 $\mathrm{min}$ ), while secretion returned only to the elevated basal levels of controls when $2.5 \mathrm{mM} \mathrm{Ca}^{2+}$ was returned (second arrow) (50-70 min). After $50 \mathrm{~min}$ in $\mathrm{Ca}^{2+}$-free buffer in zero glucose, cells stimulated with glucose for the first time at 50 min with $2.5 \mathrm{mM} \mathrm{Ca}^{2+}$ demonstrated the full monophasic response of control $(\wedge, n=8)$. 
rates returned only to control levels observed during the same period (50-70 min), $41.2 \pm 4.5 \mu \mathrm{U} /$ plate vs. $46.1 \pm 4.7 \mu \mathrm{U} /$ plate, but did not demonstrate the full early phase seen for control cells from 30 to $50 \mathrm{~min}(94.4 \pm 7.8 \mu \mathrm{U} /$ plate, $n=4, P<0.005)$. However, when HIT cells were perifused with zero glucose in the $\mathrm{Ca}^{2+}$-free buffer during the 30-min basal period and the initial 20-min stimulation period, and then stimulated with $19.7 \mathrm{mM}$ glucose in $\mathrm{Ca}^{2+}$-containing buffer, a full secretory response occurred (Fig. 1). The total insulin released (106.8 $\pm 11.0 \mu \mathrm{U} /$ plate, $n=8$, vs. $94.4 \pm 7.8 \mu \mathrm{U} /$ plate for controls) and the peak secretory rate $(11.1 \pm 1.1 \mu \mathrm{U} / \mathrm{min}$ per plate, $n=8$, vs. $8.7 \pm 0.8 \mu \mathrm{U} /$ plate per min for controls) were similar to the control rate during the initial stimulation with glucose (30-50 min). HIT cells perifused during the basal period in $\mathrm{Ca}^{2+}$-containing buffer and then stimulated with $19.7 \mathrm{mM}$ glucose in $\mathrm{Ca}^{2+}$-free buffer (30-70 min) failed to respond to the glucose stimulation (data not shown).

In companion static incubations, glucose-stimulated insulin secretion increased as $\mathrm{Ca}^{2+}$ in the buffer increased from 0.5 to $2.5 \mathrm{mM}$ (Fig. 2). However, insulin secretion was not stimulated above basal rates (equivalent $\mathrm{Ca}^{2+}$ concentrations and no glucose) when glucose was added in a buffer containing 0 or $0.1 \mathrm{mM}$ added $\mathrm{Ca}^{2+}$.

$\mathrm{K}^{+}$-stimulated insulin secretion: dependence on extracellular $\mathrm{Ca}^{2+}$. Increasing the $\mathrm{K}^{+}$concentration from 7 to $40 \mathrm{mM}$ at 30 min produced a rapid, monophasic increase in insulin secretion (Fig. 3, controls). This spike of insulin release was completely eliminated when the cells were perifused in $\mathrm{Ca}^{2+}$-free buffer during the basal and initial 15-min stimulation period (Fig. 3). When $2.5 \mathrm{mM} \mathrm{Ca}^{2+}$ in the presence of $40 \mathrm{mM} \mathrm{K}^{+}$was returned from 45 to $60 \mathrm{~min}$, the secretory response was reduced to $60 \%$ of the control value for the initial 15 min stimulation $(93.0 \pm 11.2 \mu \mathrm{U} /$ plate vs. $150.7 \pm 10.0 \mu \mathrm{U} /$ plate, $n=6, P<0.005$ ). If $\mathrm{Ca}^{2+}$-free buffer was present during both the 30 -min basal and initial 15 min stimulation period (0-45 $\mathrm{min})$ in $7 \mathrm{mM} \mathrm{K}^{+}$, and the cells were then stimulated for the first time with $40 \mathrm{mM} \mathrm{K}^{+}$at 45 min, a brisk spikelike secretory response was observed (Fig. 3). This response was, however, reduced to $80 \%$ of the control value (119.7 $\pm 9.2 \mu \mathrm{U} /$ plate vs. $150.7 \pm 10.0 \mu \mathrm{U} /$ plate, $n=6, P<0.05)$. If the basal buffer from 0 to $30 \mathrm{~min}$ contained $2.5 \mathrm{mM} \mathrm{Ca}^{2+}$, but the cells were stimulated with $40 \mathrm{mM} \mathrm{K}^{+}$in $\mathrm{Ca}^{2+}$-free buffer, no insulin secretion was elicited (data not shown).

In static incubations, $0.1 \mathrm{mM} \mathrm{Ca}^{2+}$ sustained a small secretory response to $40 \mathrm{mM} \mathrm{K}^{+}$, but no stimulated insulin secretion was detected with no added $\mathrm{Ca}^{2+}$ (Fig. 4). The secretory response was directly proportional to the level of added $\mathrm{Ca}^{2+}$ from 0.1 to $2.5 \mathrm{mM}$.

${ }^{45} \mathrm{Ca}^{2+}$ uptake. $40 \mathrm{mM} \mathrm{K}^{+}$stimulated a rapid, significant increase of ${ }^{45} \mathrm{Ca}^{2+}$ uptake from the external medium. By $2.5 \mathrm{~min}$ there was an increase in $\mathrm{Ca}^{2+}$ uptake (Fig. 5, $P<0.001, n=8-$

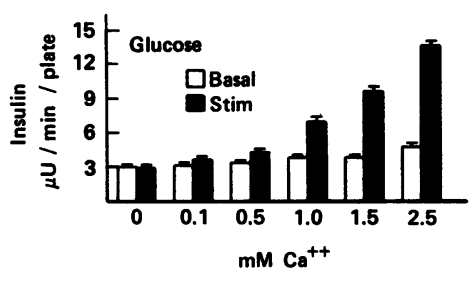

Figure 2. Glucose-stimulated insulin secretion in varying $\mathrm{Ca}^{2+}$ concentrations. HIT cells incubated in varying $\mathrm{Ca}^{2+}$ concentrations during a 60 -min basal period (basal secretion assayed from the last $15 \mathrm{~min}$, open bar, $n=8$ ) followed

by a 15 -min stimulation period in high glucose, $19.7 \mathrm{mM}$ (solid bar, $n$ $=8$ ), demonstrated a correlation between external $\mathrm{Ca}^{2+}$ concentration and insulin secretion.

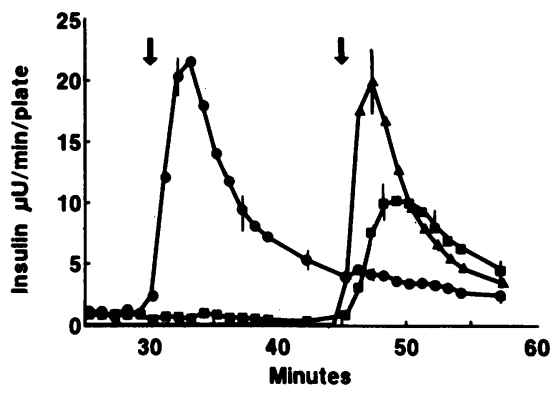

Figure 3. Calcium dependence of $\mathrm{K}^{+}$-stimulated insulin secretion. $\mathrm{K}^{+}$ $(40 \mathrm{mM})$ stimulated a first-phase secretory response $(\bullet, n=6)$ in 2.5 $\mathrm{mM} \mathrm{Ca}^{2+}$ (first arrow) and failed to stimulate in $\mathrm{Ca}^{2+}$-free buffer (30$45 \min (\mathrm{n}, n=6)$. Returning the $\mathrm{Ca}^{2+}$ (second arrow) gave a response $60 \%$ of the initial response with $\mathrm{Ca}^{2+}(\mathrm{n}, 45-60 \mathrm{~min})$. First exposure to $\mathrm{K}^{+}$with $2.5 \mathrm{mM} \mathrm{Ca}^{2+}$ at $45 \mathrm{~min}$ after a Ca${ }^{2+}$-free period in low $\mathrm{K}^{+}$ produced a monophasic response slightly less than the control response $(\Delta, n=8)$.

12 per time point), which was fourfold higher than that seen at $2.5 \mathrm{~min}$ in basal media $(P<0.001)$. The ${ }^{45} \mathrm{Ca}^{2+}$ uptake rose rapidly in a linear fashion to $5 \mathrm{~min}$, then decreased and was linear up to $60 \mathrm{~min}$. In contrast, the ${ }^{45} \mathrm{Ca}^{2+}$ uptake in high glucose alone did not increase over the uptake seen in unstimulated cells. The $\mathrm{K}^{+}$-stimulated ${ }^{45} \mathrm{Ca}^{2+}$ uptake was inhibited by verapamil (Fig. 5, inset). HIT cells preincubated for $30 \mathrm{~min}$ with 30 $\mu \mathrm{M}$ verapamil and then stimulated with $40 \mathrm{mM} \mathrm{K}^{+}$in the continued presence of verapamil had ${ }^{45} \mathrm{Ca}^{2+}$ uptake values of $8 \%$ of $\mathrm{K}^{+}$-stimulation in the absence of verapamil at $1 \mathrm{~min}, 14 \%$ at 5 $\mathrm{min}, 28 \%$ at $10 \mathrm{~min}$, and $17 \%$ at $15 \mathrm{~min}$, (each point, $n=4, P<0.001)$.

Insulin secretion from quin 2-loaded cells. The ability of suspensions of quin 2-loaded cells to release insulin in response to $40 \mathrm{mM} \mathrm{K}^{+}$and $19.6 \mathrm{mM}$ glucose was tested (Fig. 6). The addition of quin 2 causes a drop in the basal secretory rates of the glucosestimulated cells $(P<0.005, n=4)$. In quin 2-loaded cells, an increase in the $\mathrm{K}^{+}$concentration of the buffer from 7 to $40 \mathrm{mM}$ increased insulin release by $167 \%(n=4, P<0.002)$, whereas changing from 0 to $19.7 \mathrm{mM}$ glucose increased insulin release by $97 \%(n=4, P<0.005)$. In control cells treated with DMSO alone, $40 \mathrm{mM} \mathrm{K}^{+}$caused a $224 \%$ increase $(n=4, P<0.002)$ and $19.7 \mathrm{mM}$ glucose a $91 \%$ increase $(n=4, P<0.01)$. Quin 2 loading caused a significant reduction in the amount of insulin released in response to $\mathrm{K}^{+}$-stimulation $(n=4, P<0.005)$, but not glucose. The control and stimulated release in cells in suspension is much less than that of cells grown in monolayer.

Fluorescence measurements with $\mathrm{K}^{+}$stimulation. Fig. 7 shows a representative experiment illustrating the changes in $\left[\mathrm{Ca}^{2+}\right]_{\mathrm{i}}$ in cells treated with $40 \mathrm{mM} \mathrm{K}{ }^{+}$. Fig. $7 \mathrm{~A}$ shows the control experiment in which the resting $\left[\mathrm{Ca}^{2+}\right]_{i}$ was $42 \mathrm{nM}$. The addition

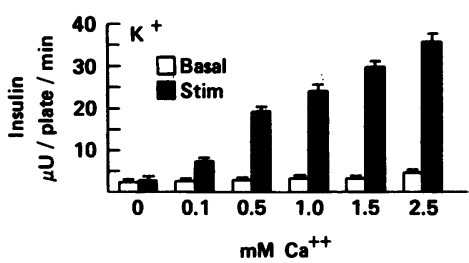

Figure 4. $\mathrm{K}^{+}$-stimulated secretion with different calcium concentrations. Low concentrations of $\mathrm{Ca}^{2+}(0.1$ and $0.5 \mathrm{mM}$ ) sustained a large portion of the insulin secretory response to $\mathrm{K}^{+}$ (solid bar, $n=8$ ) relative to rates in basal buffer with corresponding $\mathrm{Ca}^{2+}$ concentration (open bars, $n=8$ ). 


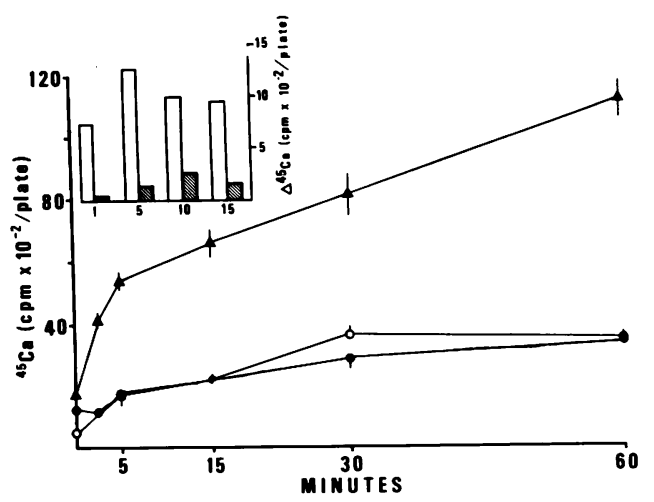

Figure $5 .{ }^{45} \mathrm{Ca}^{2+}$ uptake by HIT cells. HIT cells stimulated with 40 $\mathrm{mM} \mathrm{K}^{+}(\Delta, n=9$ per time point) demonstrated a rapid increase in ${ }^{45} \mathrm{Ca}^{2+}$ from 0 to $5 \mathrm{~min}$ and a slower linear increase from 5 to $60 \mathrm{~min}$. High glucose (o, $n=4-6$ per time point) failed to increase ${ }^{45} \mathrm{Ca}^{2+}$ uptake above basal values $(\bullet, n=18$ per time point). As shown in the inset, the change in ${ }^{45} \mathrm{Ca}^{2+}$ uptake above basal values $\left(\Delta^{45} \mathrm{Ca}\right)$ stimulated by $\mathrm{K}^{+}$(open bars) was significantly inhibited after a 30 min preexposure to $30 \mu \mathrm{M}$ verapamil followed by stimulation with $\mathrm{K}^{+}$in the continued presence of verapamil (hatched bars) at each time point tested $(n=4)$.

of $40 \mathrm{mM} \mathrm{K}^{+}$resulted in a rapid rise in $\left[\mathrm{Ca}^{2+}\right]_{i}$, which peaked at $40 \mathrm{~s}$ and remained above the basal $\left[\mathrm{Ca}^{2+}\right]_{\mathrm{i}}$ for up to $4.5 \mathrm{~min}$. $40 \mathrm{mM} \mathrm{K}^{+}$stimulated an average 4.7 -fold rise in $\left[\mathrm{Ca}^{2+}\right]_{\mathrm{i}}$ from $56 \pm 3$ to $238 \pm 7 \mathrm{nM}(n=31, P<0.001$, Table I).

If verapamil, a blocker of voltage-sensitive, $\mathrm{Ca}^{2+}$ channels was added at concentrations of $30 \mu \mathrm{M}$ or higher before the addition of $40 \mathrm{mM} \mathrm{K}{ }^{+}$, no rise in the $\left[\mathrm{Ca}^{2+}\right]_{i}$ was seen (Fig. $7 \mathrm{~B}$ ). Furthermore, the addition of 4 mM EGTA before addition of $\mathrm{K}^{+}$also completely blocked the increase in $\left[\mathrm{Ca}^{2+}\right]_{\mathrm{i}}$ (Fig. $7 \mathrm{C}$ ). The rapid fall in the basal $\left[\mathrm{Ca}^{2+}\right]_{\mathrm{i}}$ after addition of EGTA results from the quenching of extracellular quin 2 fluorescence by the binding of $\mathrm{Ca}^{2+}$ to EGTA.

Fluorescence measurements with glucose stimulation. Increasing glucose from 0 to $19.7 \mathrm{mM}$ caused a slight, but significant fall in $\left[\mathrm{Ca}^{2+}\right]_{\mathrm{i}}$ (Fig. $8 \mathrm{~A}$ ). In 11 experiments, $\left[\mathrm{Ca}^{2+}\right]_{\mathrm{i}}$ fell from $37 \pm 4$ to $31 \pm 4 \mathrm{nM} \mathrm{Ca}^{2+}(P<0.001$, Table I). If cells were loaded in the presence of nonstimulatory concentrations of glucose $(1.67 \mathrm{mM})$, there was no change in the basal $\left[\mathrm{Ca}^{2+}\right]_{i}$, but

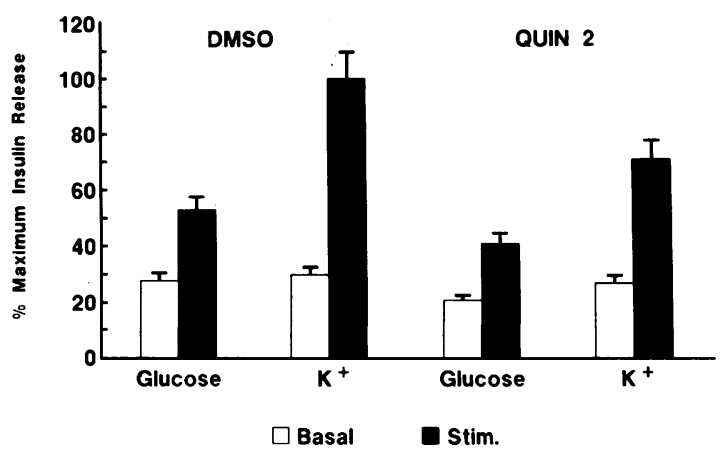

Figure 6. Insulin secretion from quin 2 loaded and control (sham loaded) HIT cells. Quin 2-loaded cells were treated as described in Methods. Control cells were not exposed to quin 2. After a 45-min basal preincubation period, insulin release was measured for a 15-min basal period in the presence of 0 or $1.67 \mathrm{mM}$ glucose, and for $15 \mathrm{~min}$ after addition of $19.7 \mathrm{mM}$ glucose or $40 \mathrm{mM} \mathrm{K}^{+}$. the slight drop in $\left[\mathrm{Ca}^{2+}\right]_{\mathrm{i}}$ was not observed upon addition of a stimulatory dose of glucose (Fig. $8 \mathrm{~B}$ ). As shown in Figs. 1-4, $40 \mathrm{mM} \mathrm{K}^{+}$is a more potent stimulus of insulin secretion than $19.7 \mathrm{mM}$ glucose. It is possible that with the smaller secretory signal a small increase of $\left[\mathrm{Ca}^{2+}\right]_{i}$ might be lost in the rapid redistribution of $\mathrm{Ca}^{2+}$ in glucose-stimulated cells. Thus, we determined a concentration of $\mathrm{K}^{+}$that stimulated approximately the same threefold increase in insulin release as that of glucose. 15 $\mathrm{mM} \mathrm{K} \mathrm{K}^{+}$increased insulin secretion 2.9-fold from 2.6 \pm 0.1 to $7.6 \pm 0.4 \mu \mathrm{U} / \mathrm{min}$ per plate $(P<0.0005, n=8)$. With $15 \mathrm{mM}$ $\mathrm{K}^{+},\left[\mathrm{Ca}^{2+}\right]_{\mathrm{i}}$ was still increased 1.5 -fold from $43 \pm 2$ to $66 \pm 5 \mathrm{nM}$ $(P<0.01, n=4)$.

Fluorescence measurements with $1 \mathrm{mM}$ EGTA or verapamil alone. Since it was shown that perifusion of HIT cells for a 30min period in the absence of extracellular $\mathrm{Ca}^{2+}$ plus 1 mM EGTA inhibited the acute release of insulin to both secretagogues, we tested the effect of this treatment on HIT cell $\mathrm{Ca}^{2+}$ homeostasis. During the 30 -min period basal, $\left[\mathrm{Ca}^{2+}\right]_{\mathrm{i}}$ fell significantly from $42 \pm 5 \mathrm{nM}(n=5)$ to $14 \pm 2 \mathrm{nM}(n=6, P<0.001$, Table I). When $40 \mathrm{mM} \mathrm{K}^{+}$was added in the presence of $\mathrm{Ca}^{2+}$, the increase in $\left[\mathrm{Ca}^{2+}\right]_{\mathrm{i}}$ to $380 \pm 51 \mathrm{nM}$ was not significantly different from that found in control cells treated with $40 \mathrm{mM} \mathrm{K}^{+}$alone.

Since verapamil itself may have an effect on basal $\left[\mathrm{Ca}^{2+}\right]_{i}$, $30 \mu \mathrm{M}$ verapamil was incubated for $15 \mathrm{~min}$ with quin 2-loaded cells in the presence of low glucose and lowered the basal $\left[\mathrm{Ca}^{2+}\right]_{i}$ slightly. At $15 \mathrm{~min}$ the $\left[\mathrm{Ca}^{2+}\right]_{\mathrm{i}}$ in control cells was $48 \pm 2 \mathrm{nM}$ vs. $39 \pm 4 \mathrm{nM}(n=3, P<0.02)$.

Actions of verapamil on high $\mathrm{K}^{+}$- and glucose-stimulated insulin release and $\left[\mathrm{Ca}^{2+}\right]_{i}$. Glucose- or $\mathrm{K}^{+}$-stimulated insulin release was inhibited by verapamil in a dose-dependent manner (Fig. 9). Complete inhibition of glucose-stimulated insulin secretion was achieved at $100 \mu \mathrm{M}$ verapamil. The dose giving the half-maximal effect $\left(\mathrm{ED}_{50}\right)$ for glucose-stimulated insulin secretion was $1.4 \times 10^{-5} \mathrm{M}$. Verapamil inhibited $40 \mathrm{mM} \mathrm{K}^{+}$-stimulated insulin release at much lower concentrations than those required to attenuate glucose-stimulated insulin release. At 1 $\mu \mathrm{M}$ verapamil, $40 \mathrm{mM} \mathrm{K}^{+}$-stimulated insulin release was inhibited to $15 \%$ of control, whereas glucose-stimulated insulin release was still $88 \%$ of control. Over a narrow range of verapamil concentrations, both glucose- and $\mathrm{K}^{+}$-stimulated insulin secretion are inhibited in a linear manner. The ranges of verapamil concentrations that produce these effects vary between the two secretagogues. From $100 \mathrm{nM}$ to $7.5 \mu \mathrm{M}$ verapamil, $\mathrm{K}^{+}$-stimulated insulin secretion was inhibited and gave a coefficient of determination $\left(r^{2}\right)$ of 0.98 , whereas verapamil inhibition of glucosestimulated insulin secretion in the range from 2.5 to $100 \mu \mathrm{M}$ verapamil produced an $r^{2}$ of 0.97 . At every concentration of verapamil tested, there was a remarkable agreement between the rise in $\left[\mathrm{Ca}^{2+}\right]_{i}$ and insulin secretion stimulated by $40 \mathrm{mM}$ $\mathrm{K}^{+}$. At concentrations of $10 \mathrm{nM}$ or less there was no effect of verapamil on insulin secretion or the rise in $\left[\mathrm{Ca}^{2+}\right]_{\mathrm{i}}$ triggered by $40 \mathrm{mM} \mathrm{K}^{+}$. The inhibitory effect of the drug was completely reversible. In cells treated with $100 \mu \mathrm{M}$ of verapamil and then returned to growth media overnight and restimulated, insulin secretion was similar to cells handled in the same manner, but not exposed to verapamil (data not shown).

\section{Discussion}

The functional integrity of quin 2-loaded HIT cells was established by cell viability and secretory studies. During a 15-min 

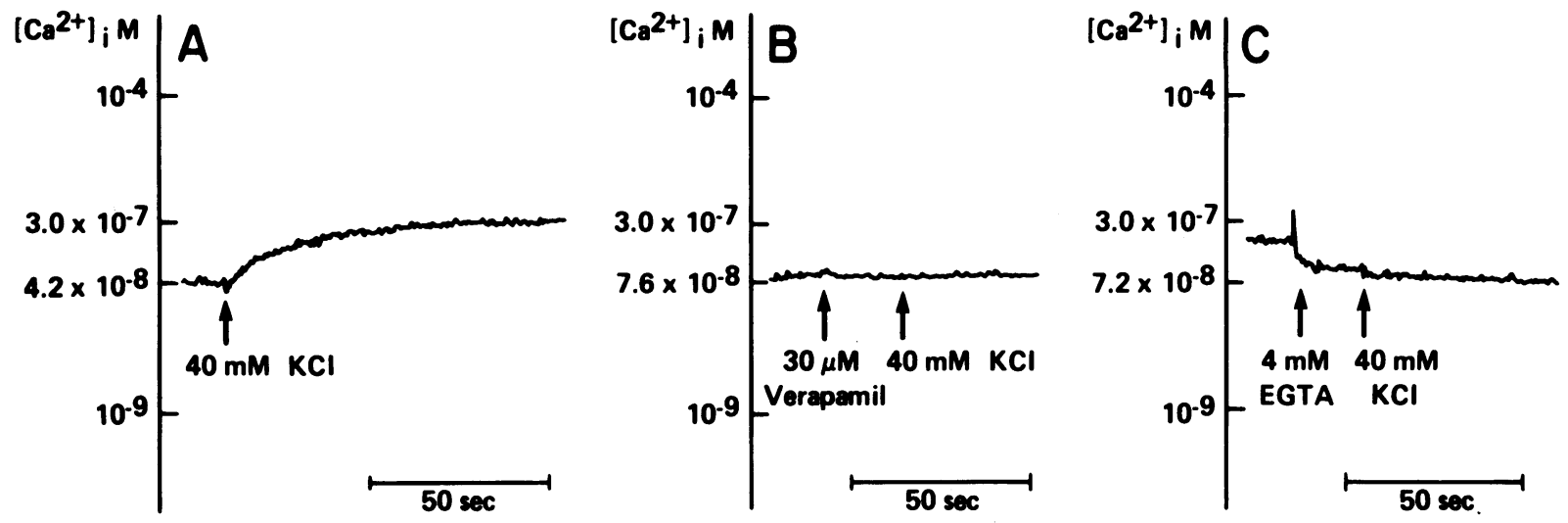

Figure 7. $\left[\mathrm{Ca}^{2+}\right]_{\mathrm{i}}$ in HIT cells, and response to $\mathrm{K}^{+} . A$ shows that $\mathrm{K}^{+}$increased the $\left[\mathrm{Ca}^{2+}\right]_{\mathrm{i}}$ from 42 to $243 \mathrm{nM}$. The effect of $\mathrm{K}^{+}$was completely blocked by prior addition of $30 \mu \mathrm{M}$ verapamil $(B)$, or $4 \mathrm{mM}$ EGTA $(C)$.

period in no glucose, the basal insulin secretory rate of quin 2loaded cells was less than that of control cells. It is not surprising that the addition of quin $2, \mathrm{a} \mathrm{Ca}^{2+}$ chelator, into the cytoplasm of a beta cell has some effect on cell function. Similar findings have been reported in the RINm5f insulinoma cells where both basal and stimulated insulin release are decreased by quin 2 loading (7). However, in both cell lines, insulin secretion in quin 2-loaded cells is still maintained, making it possible to study the role of $\left[\mathrm{Ca}^{2+}\right]_{i}$ in stimulus-secretion coupling.

These experiments in HIT cells corroborate many earlier reports in islets, demonstrating an absolute requirement for extracellular $\mathrm{Ca}^{2+}$ for $\mathrm{K}^{+}$- or glucose-stimulated insulin release. In these studies the magnitude of the secretory responses to each stimuli was dependent on the extracellular $\mathrm{Ca}^{2+}$ concentration. Although both secretagogues demonstrated a dependence on extracellular $\mathrm{Ca}^{2+}$, several differences were also apparent. Only $\mathrm{K}^{+}$ increased ${ }^{45} \mathrm{Ca}^{2+}$ uptake and $\left[\mathrm{Ca}^{2+}\right]_{\mathrm{i}}$. With high glucose the ${ }^{45} \mathrm{Ca}^{2+}$ uptake was similar to the control rate in unstimulated cells, and $\left[\mathrm{Ca}^{2+}\right]_{\mathrm{i}}$ did not increase. The $40 \mathrm{mM} \mathrm{K}^{+}$studies establish that, as in pancreatic islets (4), a rise in $\left[\mathrm{Ca}^{2+}\right]_{i}$ in the HIT cell can trigger insulin release without the presence of glucose. High concentrations of $\mathrm{K}^{+}$are a standard means of depolarizing the plasma membrane and opening voltage-dependent, $\mathrm{Ca}^{2+}$ channels (23). In RINm5f cells, high $\mathrm{K}^{+}$simultaneously alters the

Table I. Basal and Stimulated $\left[\mathrm{Ca}^{2+}\right]_{i}$ in HIT Cell Line

\begin{tabular}{lllll}
\hline & {$\left[\mathrm{Ca}^{2+}\right]_{\mathrm{i}}$} & & \\
\cline { 2 - 4 } Glucose & Basal & $40 \mathrm{mM} \mathrm{K}^{+}$ & $\begin{array}{l}19.7 \mathrm{mM} \\
\text { glucose }\end{array}$ & $\begin{array}{l}\text { Fold } \\
\text { stimula- } \\
\text { tion }\end{array}$ \\
\hline 0 & $37 \pm 4(11)$ & & $31 \pm 4(11)^{*}$ & \\
$1.67 \mathrm{mM}$ & $37 \pm 5(9)$ & & $37 \pm 5(09)$ & \\
$1.67 \mathrm{mM}$ & $56 \pm 3(31)$ & $238 \pm 17(31)^{*}$ & & 4.7 \\
$1.67 \mathrm{mM}$ & & & & \\
$\quad+1 \mathrm{mM}$ EGTA & $14 \pm 2(6) \ddagger$ & $380 \pm 51(6)^{*}$ & 27.1 \\
$1.67 \mathrm{mM}$ & $42 \pm 5(5)$ & $507 \pm 103(5)^{*}$ & 12.1 \\
\hline
\end{tabular}

Cells were incubated in basal buffer for $20 \mathrm{~s}$, and the basal $\left[\mathrm{Ca}^{2+}\right]_{\mathrm{i}}$ given is the average $\left[\mathrm{Ca}^{2+}\right]_{\mathrm{i}}$ over the first $10 \mathrm{~s}$. The stimulatory substance was then added as a concentrated bolus, and cell fluorescence monitored for $2 \mathrm{~min}$. The $\left[\mathrm{Ca}^{2+}\right]_{\mathrm{i}}$ listed is the average $\left[\mathrm{Ca}^{2+}\right]_{\mathrm{i}}$ for the last $10 \mathrm{~s}$ of each stimulatory period. Data are given as means $\pm \mathrm{SE}(n)$. $* P<0.001$ from basal.

$\ddagger P<0.001$ from basal in presence of $\mathrm{Ca}^{2+}$. membrane potential (7) and increases $\left[\mathrm{Ca}^{2+}\right]_{\mathrm{i}}$. In either cell line, blocking the $\mathrm{Ca}^{2+}$ channel with verapamil, or chelating extracellular $\mathrm{Ca}^{2+}$ with EGTA, abolishes the effects of $\mathrm{K}^{+}$on $\left[\mathrm{Ca}^{2+}\right]_{\mathrm{i}}$ and insulin secretion. $\mathrm{K}^{+}$did not stimulate insulin release in the absence of extracellular $\mathrm{Ca}^{2+}$ and the insulin secretory response was linear from 0.1 to $2.5 \mathrm{mM} \mathrm{Ca}^{2+}$. The minimum concentration of extracellular $\mathrm{Ca}^{2+}$ required for glucose-stimulated insulin secretion from HIT cells was similar to that seen in vitro in islets and was above $0.1 \mathrm{mM}(26)$. In perifusion no insulin secretion was detected in $\mathrm{Ca}^{2+}$-free buffer containing $1 \mathrm{mM}$ EGTA. As shown with quin 2 measurements, exposure to a $\mathrm{Ca}^{2+}$-free, EGTA buffer disrupts cellular $\mathrm{Ca}^{2+}$ homeostasis, lowers the basal $\left[\mathrm{Ca}^{2+}\right]_{i}$, and may deplete $\mathrm{Ca}^{2+}$ stores. However, the lack of stimulated insulin release to both secretagogues by the $\mathrm{Ca}^{2+}$-free, EGTA buffer was not due to irreversible damage to the cells, since replacing the $\mathrm{Ca}^{2+}$ elicited a recovery of secretion after the $\mathrm{Ca}^{2+}$-free period.

The insulin secretory recoveries observed when $\mathrm{Ca}^{2+}$ was returned after exposing the HIT cells to glucose or $\mathrm{K}^{+}$in $\mathrm{Ca}^{2+}$ free medium also differed. Reintroduction of $40 \mathrm{mM} \mathrm{K}^{+}$in 2.5 $\mathrm{mM} \mathrm{Ca}^{2+}$ restored insulin secretion to $80 \%$ of the control period. If high glucose was present during the $\mathrm{Ca}^{2+}$-free period, reintroduction of $\mathrm{Ca}^{2+}$ with high glucose restored insulin secretion only to the basal rate. However, if no glucose was present during the $\mathrm{Ca}^{2+}$-free period, a full first phase insulin response was triggered by reintroduction of high glucose and $2.5 \mathrm{mM} \mathrm{Ca}^{2+}$.

These observations are somewhat similar to data reported by Frankel et al. (27), who compared glucose-stimulated insulin release with the membrane potentials of single beta cells at vary-
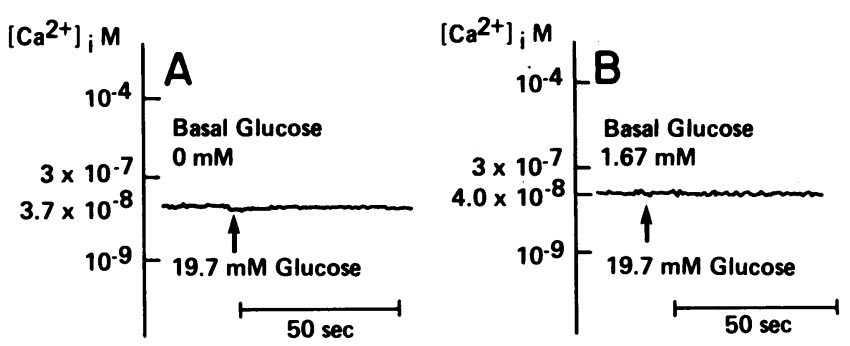

Figure $8 .\left[\mathrm{Ca}^{2+}\right]_{\mathrm{i}}$ in HIT cells, and response to glucose. HIT cells incubated in basal medium without glucose responded to the addition of $19.7 \mathrm{mM}$ glucose with a decrease in $\left[\mathrm{Ca}^{2+}\right]_{\mathrm{i}}$ from 37 to $31 \mathrm{nM}(A)$. When the basal incubation is carried out in buffer containing 1.67 $\mathrm{mM}$ glucose, no change in $\left[\mathrm{Ca}^{2+}\right]_{i}$ is seen upon addition of $19.7 \mathrm{mM}$ glucose $(B)$. 


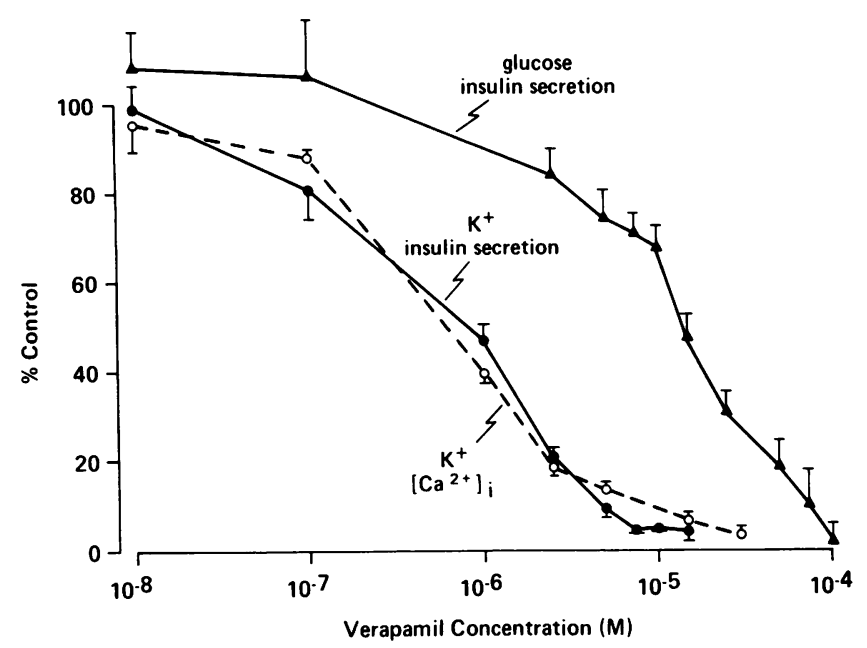

Figure 9. Effect of verapamil on $\left[\mathrm{Ca}^{2+}\right]_{\mathrm{i}}$ and insulin secretion. Cells were exposed to verapamil at the indicated concentrations. Results are plotted as percentage of control, where control is the response in the absence of inhibitor. Glucose-stimulated insulin secretion was inhibited by verapamil $(\Lambda, n=8)$ at higher concentrations than those needed to inhibit $\mathrm{K}^{+}$-stimulated insulin secretion $(\bullet, n=8)$. Inhibition of the rise in $\left[\mathrm{Ca}^{2+}\right]_{i}$ stimulated by verapamil $(0, n=5-6)$ paralleled the effect of verapamil on $\mathrm{K}^{+}$-stimulated secretion.

ing $\mathrm{Ca}^{2+}$ and $\mathrm{Mg}^{2+}$ concentrations. Depolarization of the cell was associated with insulin release, and hyperpolarization with its suppression, irrespective of the $\mathrm{Ca}^{2+}$ concentration. Readdition of $\mathrm{Ca}^{2+}$ after a $\mathrm{Ca}^{2+}-\mathrm{Mg}$-free period caused hyperpolarization of the cell membrane and suppression of glucose-stimulated insulin release. They postulated that the suppression of glucose-stimulated insulin release by readdition of extracellular $\mathrm{Ca}^{2+}$ occurs because the rise in $\left[\mathrm{Ca}^{2+}\right]_{\mathrm{i}}$ increases intracellular $\mathrm{K}^{+}$ permeability, which would hyperpolarize the cell membrane. Frankel's study (27) also shows that the relative concentrations of extracellular $\mathrm{Ca}^{2+}$ and $\mathrm{Mg}^{2+}$ are more important in glucosestimulated secretion than the absolute level of either.

One could also speculate that another explanation for these inhibitory effects is that at stimulatory concentrations, glucose could generate a transitory intracellular signal or "second" messenger. The quin 2 data indicates this signal is not a rise in $\left[\mathrm{Ca}^{2+}\right]_{\mathrm{i}}$. When $\mathrm{Ca}^{2+}$ alone was reintroduced in the presence of high glucose, the glucose signal appears to have already been inactivated or metabolized in the $20 \mathrm{~min} \mathrm{Ca}^{2+}$-free period, since insulin secretion was not stimulated and only returned to the basal state. In cells not exposed to high glucose during the $\mathrm{Ca}^{2+}$ free perifusion, the return of $\mathrm{Ca}^{2+}$ plus high glucose triggered a full secretory response. However, the lack of insulin secretion in $\mathrm{Ca}^{2+}$-free media cannot be used as evidence that $\mathrm{Ca}^{2+}$ is the intracellular signal that triggers insulin release. In the absence of extracellular $\mathrm{Ca}^{2+}$, exocytosis to all HIT cell secretagogues tested is blocked, including those which elevate intracellular cAMP levels that also trigger the acute release of insulin without increasing $\left[\mathrm{Ca}^{2+}\right]_{i}$ (Hill, R. S., J. M. Oberwetter, and A. E. Boyd III, submitted for publication). The glucose-induced signal could result from the metabolism of glucose itself or be a glycolytic intermediate, or enzyme (28), or involve the hydrolysis of phosphoinositides with the generation of diacylglycerol and inositol trisphosphate (29).

A number of previous studies using isolated islets suggest that glucose activates insulin secretion by increasing $\left[\mathrm{Ca}^{2+}\right]_{\mathrm{i}}$ via an effect on voltage-dependent $\mathrm{Ca}^{2+}$ channels. Glucose-stimulated insulin secretion is associated with an increase in the frequency of action potentials (30). High concentrations of D600, an analogue of verapamil, inhibit this electrical spike activity (31), and the $\mathrm{Ca}^{2+}$ channel blocker also causes a dose-dependent inhibition of first-phase insulin secretion (32). The dependency of glucose-stimulated insulin secretion on extracellular $\mathrm{Ca}^{2+}(4$, 5 ) and the glucose-mediated increase in ${ }^{45} \mathrm{Ca}^{2+}$ uptake into islets (reviewed in reference 4 ) also has been used as evidence that glucose may cause $\left[\mathrm{Ca}^{2+}\right]_{\mathrm{i}}$ to rise by triggering an influx of $\mathrm{Ca}^{2+}$ through voltage-dependent $\mathrm{Ca}^{2+}$ channels.

The present experiments and Wollheim's work (12) now clearly establish that $\mathrm{Ca}^{2+}$ uptake through voltage-dependent $\mathrm{Ca}^{2+}$ channels does not activate the immediate release of insulin stimulated by glucose. Although, in isolated islets, glucose increases ${ }^{45} \mathrm{Ca}^{2+}$ uptake, $5 \mu \mathrm{M}$ verapamil completely abolishes this rapid uptake, but does not significantly decrease the first phase of insulin secretion (12). Thus, it is possible to dissociate the effect of glucose on $\mathrm{Ca}^{2+}$ uptake from first-phase insulin secretion. In the HIT cells we saw no increase in ${ }^{45} \mathrm{Ca}^{2+}$ uptake during glucose-stimulated insulin release. In isolated islets, verapamil inhibited the second phase of insulin secretion by $55 \%$, suggesting that verapamil-sensitive $\mathrm{Ca}^{2+}$ channels are important in regulating the sustained release of insulin (12). We did not address that point in the HIT cells, since glucose alone does not stimulate a biphasic secretory pattern in this model system.

There is remarkable agreement between the inhibitory effects of verapamil on $\mathrm{K}^{+}$-stimulated insulin secretion observed by Wollheim (12) in islets and our data in HIT cells. $5 \mu \mathrm{M}$ verapamil decreases insulin secretion by $60 \%$ in islets (12), and $2.5 \mu \mathrm{M}$ verapamil caused a similar degree of inhibition of secretion from HIT cells. Wollheim (12) explains some of the discrepancies in the literature on the inhibitory effects of verapamil or its analogues on the first phase of glucose-stimulated insulin release, by pointing out that in previous studies the islets were exposed to the drugs for lengthy periods before addition of the glucose stimulus. This could allow the drug time to gain access to intracellular sites or result in $\mathrm{Ca}^{2+}$ depletion before the glucose stimulus. In cell lines, the inhibitory effect of verapamil on the $\left[\mathrm{Ca}^{2+}\right]_{i}$ rise and insulin secretion triggered by $\mathrm{K}^{+}$occurs almost immediately, and can be seen if both the secretagogue and inhibitor are added simultaneously.

There is a striking correlation between the inhibitory effects of verapamil on insulin release and the rise in $\left[\mathrm{Ca}^{2+}\right]_{i}$ stimulated by $\mathrm{K}^{+}$. The $\mathrm{ED}_{50}$ was $6.0 \times 10^{-7} \mathrm{M}$ for both processes. The coordinate inhibition by verapamil of $\mathrm{Ca}^{2+}$ uptake into heart muscle and pig coronary strip contractility shows a similar relationship and has a similar $\mathrm{ED}_{50}$ of $1.5 \times 10^{-7} \mathrm{M}(33,34)$. In contrast, the inhibitory effect of verapamil on glucose-stimulated insulin secretion required much higher concentrations, with an $\mathrm{ED}_{50}$ of $1.4 \times 10^{-5} \mathrm{M}$. This $\mathrm{ED}_{50}$ compares with that observed when verapamil is used to inhibit thyrotropin-releasing hormone (TRH)-stimulated prolactin release of $3 \times 10^{-5} \mathrm{M}(23)$. Since the immediate release of prolactin by TRH is thought to be triggered when $\mathrm{Ca}^{2+}$ is released from a "superficial," internal pool of $\mathrm{Ca}^{2+}$ (35), taken together these data suggest that at high concentrations verapamil may have intracellular inhibitory effects on secretion that are not related to an action of the drug on the voltage-dependent channel in the plasma membrane.

In these studies, a change in the total $\left[\mathrm{Ca}^{2+}\right]_{i}$ was not linked to glucose-stimulated insulin release. Recently, studies using the patch-clamp method to study periodic electrical activity of pan- 
creatic islets cell membranes suggest an electrical explanation for the differences in the signaling mechanisms between glucose and $40 \mathrm{mM} \mathrm{K}^{+}$. Two laboratories have independently identified a new, $\mathrm{K}^{+}$-selective channel that is insensitive to varying concentrations of intracellular-free $\mathrm{Ca}^{2+}$ and $\mathrm{pH}$ (36), but is inhibited by ATP or the metabolism of glucose (37). These $\mathrm{K}^{+}$-selective channels may link the metabolism of glucose and the signaling of insulin secretion by mechanisms independent of the voltagedependent $\mathrm{Ca}^{2+}$ channel. It is also clear from the patch clamp studies that there is a second distinct class of $\mathrm{Ca}^{2+}$ channels in the islet that are activated by membrane depolarization by $\mathrm{K}^{+}$ as well as by cytoplasmic $\mathrm{Ca}^{2+}(38)$. These are the verapamilsensitive, $\mathrm{Ca}^{2+}$ channels that allow $\mathrm{Ca}^{2+}$ influx into the HIT cell that activates insulin release by $40 \mathrm{mM} \mathrm{K}^{+}$.

Our experiments could miss a small, but physiologically significant, localized increase in $\left[\mathrm{Ca}^{2+}\right]_{i}$ in HIT cells exposed to glucose. The quin 2 technique measures the average $\left[\mathrm{Ca}^{2+}\right]_{i}$ in the entire population of cells. Based on marked differences in $\left[\mathrm{Ca}^{2+}\right]_{\mathrm{i}}$ measurements in platelets loaded with either quin 2 or the $\mathrm{Ca}^{2+}$-sensitive photoprotein, aequorin, Johnson et al. (39) have suggested that quin 2 may not detect a rise in $\left[\mathrm{Ca}^{2+}\right]_{i}$ in a localized area of the cytoplasm where only a small fraction of the total intracellular quin 2 would be available for binding to $\mathrm{Ca}^{2+}$.

Our laboratory (19), as well as others $(40,41)$, have shown that calmodulin appears to be involved in glucose-stimulated insulin release. The $K_{d}$ for calmodulin is $2.5 \mu \mathrm{M}(42)$, and quin 2 is insensitive to changes in $\mathrm{Ca}^{2+}$ between 1 and $10 \mu \mathrm{M} \mathrm{Ca}^{2+}$ (14). Using a morphologic technique that quantitates $\mathrm{Ca}^{2+}$ by precipitation of cations with pyroantimonate, Lenzen et al. (43) have examined localized changes in the distribution of $\mathrm{Ca}^{2+}$ in beta cells of perifused pancreases of mice. At the internal surface of the beta cell membrane they find a pool of $\mathrm{Ca}^{2+}$ that rapidly shifts into the cytoplasm in association with the release of insulin triggered by glucose. Two other observations suggest a need for caution in considering a $\mathrm{Ca}^{2+}$-independent signal for glucosestimulated insulin release. First, in a preliminary report, Prentki et al. (8) showed that glucose caused a rise in $\left[\mathrm{Ca}^{2+}\right]_{i}$ in suspensions of normal beta cells. Second, the triose glyceraldehyde, which enters glycolysis at a step later than glucose, alters the handling of $\mathrm{Ca}^{2+}$ by the RINm5f cells and increases $\left[\mathrm{Ca}^{2+}\right]_{i}(7)$. Using EGTA and verapamil, Wollheim concluded, like we did in these studies, that the extracellular $\mathrm{Ca}^{2+}$ pool played only a minor part in the increase in $\left[\mathrm{Ca}^{2+}\right]_{\mathrm{i}}$ with glyceraldehyde and presumably glucose (7). However, they suggested that an intracellular shift of $\mathrm{Ca}^{2+}$ is the signal for glucose-stimulated insulin release. Thus, further studies are necessary to determine if the signal that triggers glucose-stimulated insulin secretion in the HIT cell line is a localized increase in $\mathrm{Ca}^{2+}$, and if it is similar to the physiologic signaling process in the normal islet beta cell.

In conclusion, the experiments presented here show that while HIT cell insulin secretion to high $\mathrm{K}^{+}$and glucose is dependent on extracellular $\mathrm{Ca}^{2+}$, it is only for $\mathrm{K}^{+}$-stimulated insulin release that $\mathrm{Ca}^{2+}$ has an intracellular role as a trigger for exocytosis. The amount of insulin secreted in response to stimulation with $40 \mathrm{mM} \mathrm{K}^{+}$is directly proportional to the amount of $\mathrm{Ca}^{2+}$ taken into the HIT cell through voltage-dependent $\mathrm{Ca}^{2+}$ channels. Glucose stimulation, on the other hand, does not trigger an uptake of extracellular $\mathrm{Ca}^{2+}$ or an increase of $\left[\mathrm{Ca}^{2+}\right]_{i}$. While we cannot rule out the possibility that a glucose-stimulated change in $\left[\mathrm{Ca}^{2+}\right]_{i}$ is either compartmentalized, too small, or too transient to be detected by the quin 2 technique, this does not seem likely.
Furthermore, while $\mathrm{K}^{+}$-stimulation produces a long-lasting intracellular secretory signal, the glucose signal is transitory.

\section{Acknowledgments}

We greatly appreciate the advice and criticism of Teresita Yap Nelson, the technical assistance of Cheryl Neal, and the secretarial assistance of Donna Turnquist.

This work was supported by National Institutes of Health grant R01AM 34447 and Diabetes and Endocrinology Research Center grant AM 27685.

\section{References}

1. Hill, R. S., and A. E. Boyd III. 1984. Perifusion of SV40 transformed hamster $\beta$ cells to study insulin secretory dynamics. In Methods in Diabetes Research, Vol. I. Laboratory Methods, Part C. J. Larner and S. L. Pohl, editors. John Wiley \& Sons, New York. 267-276.

2. Hill, R. S., and A. E. Boyd III. 1985. Perifusion of a clonal cell line of simian virus 40-transformed beta cells: insulin secretory dynamics in response to glucose, 3-isobutyl-1-methylxanthine and potassium. $\mathrm{Di}$ abetes. 34:115-120.

3. Malaisse-Lagae, F., and W. J. Malaisse. 1971. Stimulus-secretion coupling of glucose-induced insulin release. III. Uptake of ${ }^{45} \mathrm{calcium}$ by isolated islets of Langerhans. Endocrinology. 88:72-80.

4. Wollheim, C. B., and G. W. G. Sharp. 1981. Regulation of insulin release by calcium. Physiol. Rev. 61:914-973.

5. Grodsky, G. M., and L. L. Bennett. 1966. Cation requirement for insulin secretion in the isolated perfused pancreas. Diabetes. 15:910913.

6. Wollheim, C. B., and D. Janjic. 1984. Cobalt inhibition of insulin release: evidence for an action not related to $\mathrm{Ca}^{2+}$ uptake. Am. J. Physiol. 246:C57-C62.

7. Wollheim, C. B., and T. Pozzan. 1984. Correlation between cytosolic free $\mathrm{Ca}^{2+}$ and insulin release in an insulin-secreting cell line. $J$. Biol. Chem. 259:2262-2267.

8. Prentki, M., and C. B. Wollheim. 1984. Cytosolic free $\mathrm{Ca}^{2+}$ in insulin secreting cells and its regulation by isolated organelles. Experientia (Basel). 40:1052-1060.

9. Kikuchi, M., C. B. Wollheim, G. S. Cuendet, A. E. Renold, and G. W. G. Sharp. 1978. Studies on the dual effects of glucose on ${ }^{45} \mathrm{Ca}^{++}$ efflux from isolated rat islets. Endocrinology. 102:1339-1349.

10. Malaisse, W. J., J. C. Hutton, A. Sener, J. Levy, A. Herchuelz, G. Devis, and G. Somers. 1978. Calcium antagonists and islet function. VII. Effect of calcium deprivation. J. Membr. Biol. 38:193-208.

11. Siegel, E. G., C. B. Wollheim, and G. W. G. Sharp. 1980. Glucoseinduced first phase insulin release in the absence of extracellular $\mathrm{Ca}^{2+}$ in rat islets. FEBS (Fed. Eur. Biochem. Soc.) Lett. 109:213-215.

12. Wollheim, C. B., M. Kikuchi, A. E. Renold, and G. W. G. Sharp. 1978. The roles of intracellular and extracellular $\mathrm{Ca}^{++}$in glucose-stimulated biphasic insulin release by rat islets. J. Clin. Invest. 62:451-458.

13. Kikuchi, M., C. B. Wollheim, E. G. Siegel, A. E. Renold, and G. W. G. Sharp. 1979. Biphasic insulin release in rat islets of Langerhans and the role of intracellular $\mathrm{Ca}^{++}$stores. Endocrinology. 105:1013-1019.

14. Tsien, R. Y., T. Pozzan, and T. J. Rink. 1982. Calcium homeostasis in intact lymphocytes: cytoplasmic free calcium monitored with a new, intracellularly trapped fluorescent indicator. J. Cell Biol. 94:325334.

15. Rorsman, P., P. O. Berggren, E. Gylfe, and B. Hellman. 1983. Reduction of the cytosolic calcium activity in clonal insulin-releasing cells exposed to glucose. Biosci. Rep. 3:939-946.

16. Rorsman, P., H. Abrahamsson, E. Gylfe, and B. Hellman. 1984. Dual effects of glucose on the cytosolic $\mathrm{Ca}^{2+}$ activity of mouse pancreatic $\beta$-cells. FEBS (Fed. Eur. Biochem. Soc.) Lett. 170:196-200.

17. Masiello, P., C. B. Wollheim, D. Janjic, A. Gjinovci, B. Blondel, G. A. Praz, and A. E. Renold. 1982. Stimulation of insulin release by 
glucose in a transplantable rat islet cell tumor. Endocrinology. 111:20912096.

18. Praz, G. A., P. A. Halban, C. B. Wollheim, B. Blondel, A. J. Straus, and A. E. Renold. 1983. Regulation of immunoreactive-insulin release from a rat cell line (RINm5f). Biochem. J. 210:345-352.

19. Nelson, T. Y., J. M. Oberwetter, J. G. Chafouleas, and A. E. Boyd III. 1983. Calmodulin-binding proteins in a cloned rat insulinoma cell line. Diabetes. 32:1126-1133.

20. Hales, C. N., and P. J. Randle. 1963. Immunoassay of insulin with insulin antibody precipitate. Biochem. J. 88:137-146.

21. Boyd, A. E. III, W. E. Bolton, and B. R. Brinkley. 1982. Microtubules and beta cell function: effect of colchicine on microtubules and insulin secretion in vitro by mouse beta cells. J. Cell Biol. 92:425-434.

22. Santerre, R. F., R. A. Cook, R. M. D. Crisel, J. D. Shar, R. J. Schmidt, D. C. Williams, and C. P. Wilson. 1981. Insulin synthesis in a clonal cell line of simian virus 40-transformed hamster pancreatic beta cells. Proc. Natl. Acad. Sci. USA. 78:4339-4343.

23. Tan, K.-N., and A. H. Tashjian, Jr. 1984. Voltage-dependent calcium channels in pituitary cells in culture. I. Characterization by ${ }^{45} \mathrm{Ca}^{2+}$ fluxes. J. Biol. Chem. 259:418-426.

24. Lowry, O. H., N. J. Rosebrough, A. L. Farr, and R. J. Randall. 1951. Protein measurements with the Folin phenol reagent. J. Biol. Chem. 193:265-275.

25. Zar, G. 1984. Biostatistical Analysis. Prentice-Hall, Inc., Englewood Cliffs, NJ. 150-176.

26. Curry, D. L., L. L. Bennett, and G. M. Grodsky. 1968. Requirement for calcium ion in insulin secretion by the perfused rat pancreas. Am. J. Physiol. 214:174-178.

27. Frankel, B. J., I. Atwater, and G. M. Grodsky. 1981. Calcium affects insulin release and membrane potential in islet $\beta$-cells. Am. J. Physiol. 240:C64-C72.

28. Malaisse, W. J., F. Malaisse-Lagae, and A. Sener. 1984. Coupling factors in nutrient-induced insulin release. Experientia. 40:1035-1043.

29. Nishizuka, Y. 1984. Turnover of inositol phospholipids and signal transduction. Science (Wash. DC). 255:1365-1370.

30. Dean, P. M., and E. K. Matthews. 1968. Electrical activity in pancreatic islet cells. Nature (Lond.). 219:389-390.

31. Matthews, E. K., and Y. Sakamoto. 1975. Electrical characterization of pancreatic islet cells. J. Physiol. (London). 246:421-437.
32. Devis, G., G. Somers, E. VanObberghen, and W. J. Malaisse. 1975. Calcium antagonists and islet function. I. Inhibition of insulin release by verapamil. Diabetes. 24:547-551.

33. Fleckenstein, A. G. 1971. Specific inhibitors and promoters of calcium action in excitation-contraction coupling of heart muscle and their role in the prevention or production of myocardial lesions. In Calcium and The Heart. P. Harris and L. Opie, editors. Academic Press, London. 135-188.

34. Nayler, W. G., and J. Szeto. 1972. Effect of verapamil on contractility, oxygen utilization, and calcium exchange-ability in mammalian heart muscle. Cardiovasc. Res. 6:120-128.

35. Albert, P., and A. H. Tashjian. 1984. Relationship of thyrotropinreleasing hormone-induced spike and plateau phases in cytosolic free $\mathrm{Ca}^{2+}$ concentrations to hormone secretion. J. Biol. Chem. 259:1535015363.

36. Cook, D. L., and C. N. Hales. 1984. Intracellular ATP directly blocks $\mathrm{K}^{+}$channels in pancreatic B-cells. Nature (Lond.). 311:271-273.

37. Ashcroft, F. M., D. E. Harrison, and S. J. H. Ashcroft. 1984. Glucose induces closure of single potassium channels in isolated rat pancreatic B-cells. Nature (Lond.). 312:446-448.

38. Cook, D. L., M. Ikeuchi, and W. Y. Fujimoto. 1984. Lowering of pHi inhibits $\mathrm{Ca}^{2+}$-activated $\mathrm{K}^{+}$channels in pancreatic B-cells. Nature (Lond.). 311:269-271.

39. Johnson, P. C., A. J. Ware, P. B. Cliveden, M. Smith, A. M. Dvorak, and E. W. Salzman. 1985. Measurement of ionized calcium in blood platelets with the photoprotein aequorin, comparison with quin 2. J. Biol. Chem. 260:2069-2076.

40. Sugden, M. C., M. R. Christie, and S. J. H. Ashcroft. 1979. Presence and possible role of calcium-dependent regulator (calmodulin) in rat islets of Langerhans. FEBS (Fed. Eur. Biochem. Soc.) Lett. 105:95100.

41. Valverde, I., A. Vandermeers, R. Anjaneyulu, and W. J. Malaisse. 1979. Calmodulin activation of adenylate cyclase in pancreatic islets. Science (Wash. DC). 206:225-227.

42. Rasmussen, H. 1981. Calcium and cAMP as Synarchic Messengers. John Wiley \& Sons, New York.

43. Lenzen, S., and G. Kloppel. 1984. Intracellular localization of calcium in pancreatic $\beta$-cells in relation to insulin secretion by the perfused ob/ob mouse pancreas. Endocrinology. 114:1012-1020. 